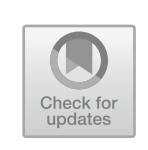

\title{
Taking Self-Help Books Seriously: The Informal Aesthetic Education of Writers
}

\author{
Alexandria Peary
}

\section{INTRODUCTION}

This chapter explores the content of self-help literature on writing, one typically omitted in traditional aesthetic education in the verbal arts. The conventional aesthetic training provided in college writing coursescreative writing workshops and to some extent in first-year composition courses, especially ones emphasizing personal essays over research discourse-exposes students to issues of subjectivity, beauty, truth, and emotional and sensory effect through close work with texts. Traditional writing courses, however, lack the sort of autotelic, holistic aesthetic that is advanced in self-help books on how to write. Not simply a package of "how-to" techniques or tips to get published, self-help books provide an experience of art akin to Dewey's holistic aesthetic experience in which the individual's qualitative, internal, and everyday lived experiences- "the movement of the organism in its entirety"-are factors (Dewey 1934, pp. 60-61; see also Moroye and Uhrmacher 2009, p. 88). It seems the rarified atmosphere of the classroom tends to preclude this type of creative

\section{A. Peary $(\bowtie)$}

Salem State University, Salem, MA, USA

(C) The Author(s) 2021

A. Masschelein and D. de Geest (eds.), Writing Manuals

for the Masses, New Directions in Book History, https://doi.org/10.1007/978-3-030-53614-5_9 
encounter. One way to understand the significance of self-help literature on writing is that it points to the concerns and interests of people outside of schools - ones that have been left unsatisfied or unanswered by traditional schooling.

Historically, significant numbers of people have been drawn to selfeducation in general and to writing self-education in particular. Self-help books were often bestsellers before "bestseller" was coined; Samuel Smiles's 1859 Self-Help: Character and Conduct, the first to use the term "self-help," sold 250,000 copies in England. Self-help books that focus on helping people write have frequented bestsellers' lists (S.n. 2004, p. 86). Since the brunt of people's lives is spent outside of formal educational settings and since learners are using self-help books to continue their postgraduation aesthetic training, writing educators might want to rethink traditional classroom pedagogy and textbooks. In a nutshell, academia can't afford to overlook the power of extracurricular aesthetic education since it enjoys considerable popular sway and has the potential to overhaul schooling upon contact.

\section{The Extracurriculum of Writing Instruction}

In terms of writing training, two discrete tracks have continuously existed inside the United States, that of classroom-situated instruction and that of informal or extracurricular instruction. Much as the formal curriculum of the university strives to provide instruction for enrolled students, the curriculum of the "extra," of that which is outside the university, strives to provide a path for people to improve their writing outside of formal coursework. The two chief delivery systems of the extracurriculum are writing self-help books (Writing Down the Bones and its ilk) and the writing group (i.e., the gathering of science fiction writers you might see meeting at a coffee shop). The texts created in the extracurriculum are primarily aesthetic, as individuals outside of schools (and working sans an instructor's assignment) tend toward creative and personal writing, not documented research papers.

The impetus for this informal aesthetic education is suggestive of why scholars should give it more serious consideration. For one, the extracurriculum has frequently served a particular demographic worthy of attention. According to Anne Ruggles Gere, individuals customarily rely on the extracurriculum in response to a lack of educational opportunity due to gendered, geographic, racial, or socioeconomic limitations 
(Gere 1994, pp. 72-92). Academic instruction in creative writing has been fraught with problems-including charges of elitism and sexism (Berlin 1987; Haake 2000; Ritter 2007). Secondly, individuals opt for the extracurriculum because of perceived problems with traditional education; this critique of academia should be examined as a sort of macro "student evaluation" of how we're doing as writing educators. As Susan Miller has argued in Textual Carnivals, when the academic discipline of Writing Studies or Composition overlooks the interests of writers, as embodied in the extracurriculum, it has "actually stripped new students and a nation of unschooled potential writers their needs and desires to create significant pieces of writing" (Miller 1991, p. 55). Moreover, academia has repeatedly benefited from contact with the various groups and organizations of the extracurriculum. Historians including Arthur Applebee, Frederick Rudolph, and Gerald Graff documented ways in which nineteenthcentury undergraduate nonacademic forums for writing (debating clubs, school literary magazines, literary societies) were absorbed by academia, resulting in such significant developments as the establishment of vernacular literary studies and creative writing (Applebee 1974; see also Graff 1987; Rudolph 1962).

Despite the benefits to formal education, academia has not made optimal use of that other strand of the extracurriculum: self-help literature. Regrettably, Writing Studies has defined itself against self-help discourses that possess considerable leverage with the general public; this othering of popular discourses has helped establish the field as a discipline but also set it up as elitist (Newkirk 2002, p. 28). One example of the potential of self-help to transform aesthetic education of the university is Peter Elbow's 1973 Writing Without Teachers - the first and to-date the only self-help book to be thoroughly embraced by writing instructors and academics. As will be discussed at the end of this article, Writing Without Teachers brought a portion of the content of self-help into the forefront of writing education and helped build the process pedagogy movement. Another example of the largely unknown influence of selfhelp on the formal curriculum is embodied in the history of a single important pedagogical device-freewriting. Process theorist Ken Macrorie is widely identified as the originator of freewriting, but Macrorie has acknowledged that he found the idea in part while attempting to improve his own writing by reading Dorothea Brande's self-help book, Becoming a Writer (Macrorie 1991). However, little subsequent cross-pollination between self-help and the formal curriculum has occurred since Elbow 
and Macrorie. A little-known 1994 HarperCollins textbook, Elaine Farris Hughes' Writing from the Inner Self, credits Dorothea Brande for some of its ideas (Hughes 1994). More recently, Gesa Kirsch mentions another self-help book, Dan Wakefield's The Story of Your Life: Writing a Spiritual Autobiography, as manifesting "several composition scholars' theories of writing development" (Kirsch 2009, pp. W3-W4). By and large, however, academia has ignored the signals sent by the informational writing education that so many people have historically utilized.

\section{Teachers as Obstacles to Writing Ability}

Critique of classroom writing instruction appears in twentieth-century writing self-help literature. In Becoming a Writer, Brande claims that most creative writing courses fail to address the "root problems" of writing and instead provide only technical or structural information. Formal classroom instruction becomes a catch-22 situation because such courses help the "hack writer" who is oblivious to the real problems of writing and at the same time just frustrate individuals with genuine talent: "instruction in writing is oftenest aimed at the oblivious tradesman of fiction, and the troubles of the artist are dismissed or overlooked" (Brande [1934] 1981, p. 28). Moreover, writing teachers are unable to help the genuinely struggling student because the teacher is "seldom a practicing author" (ibid., p. 28). In Writing Down the Bones, Goldberg claims that formal education failed to help her understand how to become a writer: "I had a sincere and earnest desire to figure out this writing life. I very badly wanted to do it and I didn't know how, and I hadn't learned how in all my public school education. By college, I think I gave up" (Goldberg [1986] 2005, p. xiii). Goldberg proposes that many people who struggle with writing fail to complete the first step of writing-to learn to believe in their own inherent ability-and instead make the mistake of seeking guidance from teachers: "[p]eople often begin writing from a poverty mentality. They are empty and they run to teachers and classes to learn about writing. We learn by doing it. That simple. We don't learn by going outside ourselves to authorities we think know about it" (ibid., $32)$.

For Ueland, the main issue with formal instruction is how the corrective mindset employed by teachers squelches creativity. Ueland gathers an assembly of negative influences on writing, authority figures who include teachers: 
You have all noticed how teachers, critics, parents, and other know-it-alls, when they see you have written something, become at once long-nosed and finicking and go through it gingerly sniffing out the flaws. AHA! a misspelled word! As though Shakespeare could spell! As though spelling, grammar and what you learn in a book about rhetoric has anything to do with freedom and the imagination! (Ueland 1938, p. 59)

This critique is encapsulated in Elbow's title, Writing Without Teachers, and in his central contention that people who want to write need to do so by writing without teachers. According to Elbow, people who struggle to write are often stymied by criticism from current teachers or past teachers whom they have internalized. In Writing Without Teachers, Elbow also lays significant blame on teachers who he says "seem to play a big role in making it harder for people to write" (Elbow [1973] 1998, p. xii). For Elbow, the tendency in teachers toward a corrective constantly evaluative mindset is one factor in writing blocks.

\section{Advocating for Universal Writing Ability}

As part of a reparative confidence-building strategy, self-help literature represents writing as a matter of human nature rather than of specialization. Both the desire to write and the ability to write are cast to varying extents as natural. When the act of composing is naturalized, the implication is that writing inhabits a larger environment than only school settings or the charmed realm of published authors. Similarly, Deweyan aesthetics "recontextualizes art as a process within experience" whereby “'Art' ceases to refer to a fixed class of objects or to a detachable essence, and the 'aesthetic' ceases to refer to a peculiar type of subjective experience" (Alexander 1987). Self-help literature also argues against a hierarchy in creative writing instruction. Hughes Mearns, a protégé of Dewey and reputed founder of classroom-based creative writing instruction, advocated for a shared human capacity for creativity in his pedagogic and self-help books from the 1920s and 1940s (Myers 1996; See also Mearns 1925; S.n. 1929; S.n. 1940). Despite its early democratization of creative ability, academic-based creative writing instruction slunk into elitism-something avoided by the extracurriculum. Exclusionary practices at Yale and Princeton in the early twentieth century, whereby only so-called gifted students were allowed entrance into creative writing courses, have been criticized by James Berlin ( 1987, pp. 39-40). 
Critiques by Katharine Haake and Kelly Ritter of current creative writing education point to the privileging of certain creative writing students, often on the basis of gender or perceived ability (Haake 2000; Ritter 2007).

All the content areas of self-help-the role of the unconscious, control, and holism-gesture to this one message: you can do it. You can write. The ability to write becomes part of every individual's endowment, an always-present capacity that doesn't require a classroom or a teacher. Instead, writing ability is extremely portable, part of the self that the writer invariably and easily brings to each new context. Whether that context happens to be part of a classroom or course work-or whether the teacher's chair is literally vacant-is merely happenstance.

\section{The Role of the Unconscious in Writing}

The trajectory of advice in self-help books on writing can be summarized as occurring in three stages that are for the most part recursively developed. First, the reader is guided through an investigation of his or her writing blocks. The self-help author suggests reasons for the block while at the same time arguing that the reader's experience of blockage-and of wanting to self-express-is natural to human beings. The net psychological effect of this rhetorical move is to provide comfort to the skeptical and possibly anxious reader, a move Jean Marie Stine and Sandra K. Dolby have described as characteristic of the genre of self-help, no matter the topic of the advice, whether it be quitting smoking, dating, or writing a novel (Stine 1997; See also Dolby 2005). Next, the self-help author assures the reader that he or she possesses an innate ability to write, and that successful composing is a matter of access. Then the self-help author tells readers that they can produce writing by exploring themselves, depicted as an inner space or mind. The message at this point is basically, "Go inward, writer." Creating becomes a matter of discovery, typically of material already present, albeit unconsciously, in the novice.

In essence, writing self-help books recast the classical rhetorical canon of invention as primarily a matter of self-engagement. This turning inward is described by self-help literature as a matter of the unconscious, as a listening to an inner voice, as discovery, and as one requiring a trusting relationship with the self (in contrast to the distrustful relationship the reader may have with writing experts). The focus on the unconscious or on the interior knowledge of novices also does much to naturalize writing 
ability and build self-esteem. In emphasizing the unconscious, the selfhelp author anticipates the self-doubt of anyone who picks up a self-help book who could be muttering, "Do I really have anything in me worth writing?" By suggesting that readers already possess material for writing (in their unconscious), the self-help author has already alleviated the sense that writing is an impossibility. And so Lamott in her best-selling 1995 Bird by Bird pronounces:

everything we need in order to tell our stories in a reasonable and exciting way already exists in each of us. Everything you need is in your head and memories, in all that your senses provide, in all that you've seen and thought and absorbed. There in your unconscious, where the real creation goes on. (Lamott 1995, p. 181)

In several self-help books on writing, creative ability is also construed as an expansively collective ability, stretching between individuals in a way reminiscent of Jung's collective unconscious. In her 1986 Writing Down the Bones, Natalie Goldberg, citing a Zen master, says that writing "[c] apability is like a water table below the surface of earth'... No one owns it, but you can tap it" (Goldberg 2005, p. 33). When Dorothea Brande in her 1934 Becoming a Writer mulls over genius-a topic potentially laden with elitism - she posits genius as a collective and unconscious ability. Creative genius is an endowment that every human being possesses and is at the same time never fully managed by any single person, no matter how great: "No human being is so poor as to have no trace of genius; none so great that he comes within infinity of using his own inheritance to the full" (Brande 1981, p. 157). Our inheritance of genius is not only beyond the manipulation of any single person's will, according to Brande, it also can't be altered or consciously taught: "You cannot add one grain to this faculty by all your conscious efforts, but there is no reason you should desire to. Its resources at the feeblest are fuller than you can ever exhaust" (ibid., 156). In this regard, the unconscious as it occurs in writing self-help literature is extracurricular: it is not something impacted or regulated by formal classroom instruction. Similarly, Natalie Goldberg proposes in Writing Down the Bones that we need to write from our original minds, a capacity which can be inhibited by analysis as well as by conventional instruction. According to Goldberg, "Stay with your original mind and write from it" (Goldberg 2005, p. 33). School 
conversely teaches people to not be attentive to their first thoughts and therefore depletes creativity.

This type of engagement with the unconscious is particularly evident in Dorothea Brande's If You Want to Write. For instance, Brande claims that instead of a lack of technique, struggling writers really suffer from "root" personality problems caused by an inability to access the unconscious (Brande 1981, p. 47). These root problems are manifested in the four difficulties commonly displayed by struggling writers: in getting started, in writing again after a previous success, in having too long empty periods between writing, and in producing texts of inconsistent quality (ibid., 47). Rather than attributable to a lack of confidence or excessive expectations, the four root problems result from a failure to access and trust the unconscious. Brande proposes that the novice writer develop a dual nature in which the conscious and unconscious mind are put in dialog: "The writer's first task is to get these two elements of his nature into balance, to combine their aspects into one integrated character. And the first step toward that happy result is to split them apart for consideration and training!" (ibid., 39). In Brande's depiction, one which correlates with a Freudian perspective, the conscious and unconscious work as a team, but the work dynamic is also one in which the two parts regulate each other. So while Brande's first task for the novice writer is that he works on connecting the conscious and unconscious through writing at the moment of waking, the conscious mind also serves as the practical partner and creates "suitable conditions" for the "artistic-self" (ibid., 49). For Brande, as with many of writing self-help authors, the first draft should be a time in which the unconscious is ascendant and the conscious mind, and especially its editorial tendencies, is on mute. At the time of composing, quality was not the correct concern for the writer: the correct goal is to connect the two parts of the mind.

That the unconscious is not within the typical purview of classroom instruction is something that has been discussed by theorists. For instance, both Donald Murray and Janet Emig have suggested that English departments fail to foster the unconscious in student writing. For Murray, writing pedagogy and theory are limited to the "exterior view of writing," overlooking the "interior view of composing seen by the practicing writer" (Murray 1970, p. 21). Adopting this interior view entails an individual exploring her own mind and discovering new material and meaning - a description akin to the unconscious. For Emig in her 1964 article, "The Uses of the Unconscious in Composing," poor student 
writing, or "surface scrapings," results from teaching students only to write consciously or "from one layer of the self" (Emig 1964, p. 6). The sense is that standard writing instruction either is unwilling or unable to help students utilize their unconscious in composing. According to Emig, the very task environment of writing instruction, including the use of weekly themes and in-class writing, is not conducive to "encounters with any but the conscious self" (ibid., p. 6).

The task environment set up by self-help fosters the unconscious in composing in a way which could be of use to writing experts. Students need to be given the rewarding experience of finding ideas in their unconscious - they need to be shown that ideas are not necessarily the derivatives of topic sentences or thesis statements. Imagine a textbook with a focus on showing students how to better access the unconscious in order to write: not just the surface desire of obtaining a good grade. Peter Elbow's device of freewriting, a widely used pedagogical device, is one method for providing students with stimulating material from the unconscious (Elbow 1998, pp. 17-19). A formal curriculum modeled on the self-help tradition could devote more of its praxis to prompts which enable students to access private imagery and form meaningful connections to the subject matter of an upcoming writing project-even an academic one. For instance, prompts which ask students to generate conceptual metaphors or similes pertaining to a topic at hand and to then reflect on new perspectives cast by those figurative phrases could allow students to connect with the unconscious (Tobin 1989, pp. 444-458).

In her self-help book, Brande offers one such prompt to evoke the conscious and unconscious tango. This marvelously simple demonstration entails drawing a circle on a piece of paper and places a cross through the circle. The reader is then to hold a ring on a string about four inches above the intersection of the cross. Keeping the hand still and trying to ignore the key, the reader is to follow the shape of the circle only with the mind. Soon, the key will be involuntarily making circles in the same direction as the mind had previously gone. Brande suggests then stilling the key and attempting the exercise again, this time moving the mind in the opposite direction in the circle to see if the key will again follow (Brande 1981, pp. 64-65)

This relationship with the unconscious is frequently cast in self-help literature on writing through the metaphor of "voice": turning inward to create involve listening to and trusting an inner voice. The terms for this "speaking part" given to the unconscious in the performance of writing 
differ between self-help books. In Bird by Bird, Ann Lamott alternatively calls the unconscious a "voice" and the "intuition." She advocates creating a metaphor for this voice or intuition which she picturesquely describes: "A friend says that his intuition is his animal: 'My animal thinks this,' he says, or 'My animal hates that.' But whatever you come up with needs to suggest a voice that you are not trying to control" (Lamott 1995, pp. 114). Lamott describes writing early drafts as listening for voice: "you get quiet and try to hear that still small voice inside" (ibid., p. 110). In If You Want to Write, Brenda Ueland equates creativity with introspection and "complete self-trust," the basic set-up for listening to voice (Ueland 1938, pp. 27-45). Natalie Goldberg extends this discussion of "listening" and equates the entire work of writing with listening to the self (Goldberg 2005, p. 58). Goldberg, like Peter Elbow, maintains that everyone possesses a genuine, interesting voice: "Everything I say as a teacher is ultimately aimed at people trusting their own voice and writing from it" (ibid., p. 165). In Writing Without Teachers, voice is equated with the power of an individual's writing, to be protected from external considerations such as audience and editing:

The habit of compulsive, premature editing doesn't just make writing hard. It also makes writing dead. Your voice is damped out by all the interruptions, changes, and hesitations between the consciousness and the page. In your natural way of producing words there is a sound, a texture, a rhythm-a voice - which is the main source of power in your writing. (Elbow 1998, p. 6)

According to Elbow, voice is an internal creative capacity-an amazing reservoir of ability - that needs to be accessed and protected in early drafts. Voice became one of Peter Elbow's signature ideas in the 1970s and 1980s as well as an important construct in academic writing instruction.

\section{Issues of Control ANd Creativity}

Imagine an ENL 101 course that includes discussion of how to manage the false tendency to try to control the writing process-or where students go wrong in trying to deal with the constant fluctuation of composing. The paradoxical side to self-help literature is that it often prods readers to renounce control while these very same readers have picked up self-help 
books in an attempt to take charge of a certain problematic area of their lives and make a change. As Victoria Leto DeFrancisco describes self-help, it is "do it yourself" repair for the mind, body, and soul" (DeFrancisco 1995, pp. 107-110). Whereas the purpose of scholarly writing is to contribute to one's field, with self-help, the focus is on the reader as an individual with the intent to aid that individual in his or her daily life (Dolby 2005; See also McGee 2005, p. 195; Starker 1989, p. 9). The very experience of struggling to write or suffering through a writer's block often leaves individuals feeling out of control. What self-help authors point out, however, is that people who are stuck in their writing often flounder because of erroneous attempts at controlling the process.

In Elbow's Writing Without Teachers, control is the umbrella category for several other issues pertaining to blocked writing - self-editing, planning, concern for quality, all of which originate in the conscious mind. In a move that Sandra Dolby describes as characteristic of the self-help genre, Elbow provides autobiographical information on his own struggles with writer's block. As Dolby says, "One latent function of self-help books is that they provide their authors with an opportunity to bear witness to their own transformation or conversion [...] permit[ing] the unabashed enthusiasm and sense of epiphany the writer is often required to keep subdued in more scholarly writing" (Dolby 2005, p. 48). In his experience attending prestigious ivy-leagues, Oxford and Harvard, much of school instruction was control-oriented and thus caused problems in Elbow's own writing. From his personal experience overcoming block, Elbow believes that people who want to write need to gain their "independence from care, control, planning, order, steering, trying to get it right, trying to get it good" (Elbow 1998, p. xvii). Throughout Writing Without Teachers, the issue of control functions as a way of talking about the differences between the unconscious and conscious parts of the writing mind. Freewriting is the primary strategy for abandoning control and obtaining ideas; in freewriting, "the integration of meanings is at a finer level than you can achieve by conscious planning or arranging" (ibid., p. 8).

Indeed, Elbow seems to redefine the rhetorical canon of invention such that it chiefly entails the relinquishment of control. Elbow relocates control, transporting it from the invention stage to the editing stage, where he says it is more appropriate. Control comes after-the-fact of writing, and the text is heavily planned out only after an initial wandering: "Control, coherence, and knowing your mind are not what you start out 
with but what you end up with" (ibid., p. 15). This message is quite a contrast to the "get-your-thinking-right-first-then-write" approach of much writing instruction in the 1960s, epitomized in this advice from a widely used 1965 textbook:

Some people like to take aimless trips, making no plans at all but rambling over the countryside, exploring side roads, stopping when they wish, and not much caring when or where they arrive. When people want to reach a definite destination at a specific time, however, they generally make detailed plans of their route and schedule their time. Writing is much the same. Some writing - letters to friends, for example - is unplanned. It rambles on aimlessly and spontaneously, making digressions and having no fixed objective. For most formal writing, however, you need a plan which shows you where you are headed and how you expect to get there. (Newkirk 2005)

Meaning-making is unconscious in that the individual may not have been aware of this content present in his or her thoughts before writing-and may not be aware of this content even while writing or dredging them up. Another aspect of this abandonment of control is allowing the words to guide one's meaning, rather than thinking that either the unconscious or conscious self is the stalwart leader through the act of composition: "You're trying to get your material to do some of the steering instead of doing it all yourself... The words are not going through stages you planned or that you control" (Elbow 1998, p. 32). This abandonment of control as advocated by the extracurriculum corresponds with the "special scope of aesthetic experience" described by Martin Seel, in which "aesthetic experience allows what is indeterminate in the determinate," increasing a viewer's awareness of the present moment (Seel 2009, p. 105). Elbow claims that, paradoxically, when a writer tries to be in charge, she frequently ends up stuck, helpless, and feeling that writing is beyond her (Elbow 1998, p. 32). For Elbow, the site of invention is not just about making an inward turn: it's also about monitoring how the self-responds to control and discouraging the self from falsely seeking control.

In a different way of addressing issues of control, Dorothea Brande and Ann Lamott both speak of writing as entering a state of self-hypnosisthe epitome of losing control. When Brande actually broaches the thorny topic of genius, she discusses it as a lack of control, as entering a state of light hypnosis in which "the attention is held, but just held" (Brande 
1981, p. 160). While mindless or repetitive activities like cleaning floors can help some individuals reach genius, Brande says the more efficient method is to quiet the mind through meditation on an object. After quieting the endless discursive thinking, the writer should introduce an idea from their writing and see what arises (ibid., p. 164). For Lamott, "Writing is about hypnotizing yourself into believing in yourself, getting some work done, then unhypnotizing yourself and going over the material coldly" (Lamott 1995, p. 114). In Goldberg's book, the mindfulness and Buddhist philosophies which pervade Writing Down the Bones obviate the need for explicit discussion of self-hypnosis. Mindfulness is similar to self-hypnosis in its calming of the self and watchfulness of mental phenomena.

A synthesis of self-help and formal writing pedagogy for the purposes of teaching students issues of control would entail drawing students' awareness, through process writing and class discussion, to their own stance toward critique and error. Another method could involve asking students to write a significant quantity of non-graded writing so that error, dull thinking, or flat language become a small, passing matter rather than a worrisome condition. By prolonging the invention phase, assigning more private writing, and allowing students to delay performing for an audience for as long as each individual requires, students can be guided toward a more helpful sense of control.

\section{The Holistic Nature of Writing}

Overall, writing self-help books propose that writing is a holistic act involving and affecting the entire person not to be compartmentalized as solely a mental phenomenon. As Richard Shusterman has said of Dewey, self-help books cast the experience of writing as naturalistic, as "grounding aesthetics in the natural needs, constitution and activities of the embodied human organism" (Shusterman 2001, p. 122). Dewey endeavored to reduce unhelpful binaries between the mind and body and between affect and logic (Dewey 1929, pp. 63-72). In self-help literature, this holistic outlook sees writing as offering intrinsic benefits beyond publication or other types of external success. Perhaps intrinsic rewards are needed because of the way in which self-help literature necessarily positions the act of writing. That is, any writing completed through the advice of a self-help book is writing that has been done outside of academia. In school settings, a theoretically clear outcome is 
promised at the finishing line of writing-grade, passing course, graduation, degree, employment-whereas in the extracurriculum, excepting publication, goals may be less clear cut. Thus, for Brande, the central task of learning to write, namely the synchronizing of the unconscious and conscious, is fundamentally holistic. It takes the whole person to let the two parts of the self make good writing decisions (Brande 1981, p. 45). The reader should keep in mind the benefit of trying her exercises which have as their "end of making a full and effective life for yourself" (ibid., p. 66). In Writing Without Teachers, Elbow links composing with "any learning that involves the whole person rather than some discrete cognitive skill” (Elbow 1998, p. 141).

Personal fulfillment, spiritual and societal benefits, and identity formation are all touted by self-help authors as the benefits of practicing one's writing-again surpassing any discrete cognitive skill. Writing can positively affect as well as involve the whole person; rather than an occasion for anxiety, writing is an all-around pleasant opportunity for connecting to oneself. In this regard, self-help aesthetics correspond with Dewey's stance that an aesthetic experience is "appreciative, perceiving, and enjoying" (Whitehead 2004). This sort of holism is evident in Composition scholar Sondra Perl's adaptation of Eugene Gendlin's theory of felt sense-in which having a creative experience is noted not only in the mind but also in the body (Perl 2004). It's also evident in Richard Shusterman's more recent concept of somaesthetics which builds off of Dewey's naturalism and which identifies the body as a source for aesthetic experience (Shusterman 2008). A writing course which adopts the holistic stance of self-help would endeavor to help students connect the act of composing to experiences in their bodies and to experiences outside the classroom in their everyday lives. While not necessarily inviting first-person pronoun texts, meta-cognitive prompts (such as asking students to insert parentheticals inside an early draft in which they reflect on what is occurring with themselves or their surroundings in the moment of writing) is one exercise to increase students' holistic sense of themselves as writers.

Self-help literature offers models for how to proceed with that holistic stance for writing. In Bird by Bird, Ann Lamott perceives writing as leading to personal fulfillment when a writer feels that "true words" have moved from inside them to the external world (Lamott 1995, p. xxxxi). Lamott also says writing can ameliorate the problems of the modern world, suggesting that writing can be a cure for narcissism by providing states of ecstasy and self-respect (ibid., pp. 99-100). Lamott concludes 
Bird by Bird with the notion that writers belong to a noble tradition in an imperfect world; writing deepens the soul and helps counter the absurdity of contemporary life (ibid., pp. 234-237). For Goldberg in Writing Down the Bones, the writing practice carries spiritual benefits, allowing a person to "become larger" than herself by following her instinctive thoughts and be "breathing in God" (Goldberg 2005, p. 10). Furthermore, writing provides satisfaction because it indicates that the individual is "fulfilling your function" by "knowing who you are, what you are supposed to be doing on this earth, and then simply doing it" (ibid., p. 44). Writing leads to a greater awareness which Goldberg calls "living twice," and literacy in general is a "constant source of life and vitality," exemplified in the Jewish tradition of giving a boy a spoon of honey after he reads his first word from the Torah (ibid., p. 53, 119). Goldberg finally sums up her esteem for the benefits of writing when she tells the reader not to worry about the quality of created texts but instead to know that the very attempt to write is "heaven" (ibid., p. 119). In a similar emphatic vein, Ueland in If You Want to Write touts the health benefits of creativity in a way which would likely not be found in a composition-rhetoric textbook, no matter the time period:

Writing, the creative effort, the use of the imagination, should come firstat least for some part of every day of your life. It is a wonderful blessing if you will use it. You will become happier, more enlightened, alive, impassioned, lighthearted, and generous to everybody else. Even your health will improve. Colds will disappear and all the other ailments of discouragement and boredom. (Ueland 1938, p. 13)

For Ueland, writing is never a waste of time, and even on the sentence level, the act of composition will benefit the individual (ibid., p. 14). Writing is such a holistic endeavor that it can positively and physically affect the writer's health in Ueland's scenario.

Self-help authors' emphasis on the intrinsic benefits to writing also entail their devaluation of publication. That self-help books on writing do not promise readers publication contradicts skepticism of self-help authors, as expressed by Tom Tiede and Wendy Kaminer, as snake oil salespeople who promise easy fixes and immediate gratification and cause conformity (Tiede 2001; See also Kaminer 1992). In fact, Lamott, Goldberg, and Ueland actively downplay publication, even suggesting that 
their stronger writing students are the ones who haven't sought publication. For Ueland in If You Want to Write, her published students are often the least interesting to her, and she frequently points out the superiority of unschooled student writing to that receiving acclaim in the mainstream magazines of the day. Ueland describes publication as one of the impediments to her own writing (Ueland 1938, p. 21). Overall, the benefits espoused in self-help literature on writing are more substantive than external rewards, and thus the self-help reader is provided multiple motivations for the hard work of writing self-education.

Connected to the intrinsic rewards of writing in self-help literature is the related notion that writing needs to be perceived as a longterm endeavor that requires daily practice. Simply put, writing requires a different timeline than one normally seen in a classroom. This developmental model makes sense given the context of self-help: it's learning that is not part of a fifteen-week course with clear tasks and provided deadlines. In Elbow's view, working on one's writing is not about an assignment immediately at hand but about improving writing for and in the future: "But you must develop a feel for the larger growth cycles too. Certain kinds of growth take longer. One has to be open and accept bad writing now-meaning this year, this decade - in order to get to good writing" (Elbow 1998, p. 47). In a similar vein, Anne Lamott suggests that one solution for a writer's block is to take a long-term view of writing by relinquishing control and patiently waiting for one's intuitive inner voice to kick in again (ibid., pp. 112-113).

Writing self-help authors frequently recommend a daily practice for writing. Not only does writing take the patience to continue with it beyond the span of a semester or course, it also requires a higher frequency of engagement than school-based writing. That is, people who want to write must do so every day, not on the days a class meets. Lamott suggests that the solution to writing problems is two-fold: develop a daily practice and lower standards (Lamott 1995, p. 22). Brande's daily schedule entails early morning freewriting to tap the unconscious, writing at a set time each day, and then once ease has been established, writing at a varied time in order to "teach yourself to write at a given moment" (Brande 1981, p. 76). In If You Want to Write, Ueland's daily practice differs from Brande's in that it emphasizes a purposeful idleness to jumpstart creativity (Ueland 1938, pp. 35-36). Formal writing instruction could coach students toward adopting a long-term view of their writing development-in which students are committed to growing as users 
of language beyond the fifteen weeks of a compartmentalized course. For example, designing major course projects that emphasize unfinished (versus polished) long texts would help instructors steer students away from artificial semester deadlines and toward a long-term view of their productions. Such projects allow students to concentrate on generating multiple new ideas rather than weeding them out-with the implication that the ideas are a resource for future written projects.

\section{Elbow's Writing Without Teachers: The Informal Affecting the Formal in Aesthetic Education}

While Lamott's Bird by Bird and Goldberg's Writing Down the Bonesand likely still Ueland's book from the 1930s-make it often to the departmental copy machine, face-down, for handouts for students, Elbow's book was the first self-help book on writing to fully pervade classroom writing instruction-and no other self-help book has done so since. Writing Without Teachers, undoubtedly one of the most influential of texts on the academic discipline of Composition Studies, paradoxically began as a self-help book. Elbow started the book as a series of private notes to help himself out of his own entrenched writer's block in graduate school (Elbow 2009). Elbow based his title off a self-education series popular in England in the 1960s with titles like Latin without Tears (ibid.). Sandra K. Dolby identifies the tendency of self-help authors to "bear witness to their own transformation or conversion" in relation to a personal challenge (Dolby 2005; See also Lee 2007; Woodstock 2006). In a similar vein, Elbow has described Writing Without Teachers as evangelical: "I didn't think of Writing Without Teachers as scholarly. I thought of it as 'I have the truth to tell everyone.'... I wanted to stand on a mountain top and tell people how they can [write]" (Elbow 2009). The self-help stance of Elbow's book is evident starting with its title-and the paradox is that Writing Without Teachers and then his subsequent Writing with Power went on to become widely used by teachers in classrooms.

What differentiates Elbow's advice from those of the other self-help books is its systematic presentation on how to go about the work of writing. In part, Elbow's different presentation may result from the fact that he is and was a faculty member in high education, unlike the other self-help authors. By the time he organized the original scraps for a booklength treatment in Writing Without Teachers, Elbow had completed a Ph.D. from Brandeis, had taught at M.I.T., and had helped establish an 
entire college (the now-defunct Franconia College). Ueland, Lamott, and Goldberg provide anecdotes of their strategies as a model for the reader or serve as a sort of commonplace book for short sound bites on writing. What they do not provide is a systematic treatment from inception to final draft. A novice who wanted to parse out a thorough composing practice for herself from these other books would have to do a great deal of work to fill in gaps; she'd practically be writing her own syllabus. One problem with self-help literature is that it is largely constructed on authors' personal accounts of struggle, thereby tacitly suggesting that the reader adopt the ways of the author/authority in the absence of empirical evidence (Lee 2007; Woodstock 2006). Another criticism of self-help books is that in their desire to assist struggling writers, self-help authors deaden reader's critical thinking capacity by providing "simple, step-bystep solutions to whatever crisis they discuss" (Kaminer 1992). Finally, self-help books tend toward the affective-using encouragement, direct address of the reader, and pathos rather than the more even-handed qualifiers of academic scholarship - and therefore may seem suspect to academic writing specialists. Elbow's work has faced critiques similar to those of self-help. As Kia Richmond and Irene Papoulis have suggested, Elbow's work has also been criticized for its subjective treatment of composition and for drawing attention to the affective dimensions of learning (Richmond 2002; see also Papoulis 2002). Specifically, Elbow's promotion of voice has been described as imparting Writing Studies with an anti-intellectual evangelicalism in which students gain a metaphoric salvation if their writing is subjectively deemed by their teachers to contain voice (Hashimoto 1994).

Given these criticisms, one could say that Elbow is just "teacherly enough" to take his teacherless approach and infuse it with an organization. That is, Elbow's Writing Without Teachers has just the right amount of "curriculum" in order to make his extracurriculum convincing. After initially vocalizing his grievance with traditional writing instruction, Elbow rolls out complex composing strategies-freewriting, then the Growing Process, followed by the Cooking Process. In addition to the composing strategies, Elbow provides advice on revision and then obtaining feedback (through a teacherless group). In Writing Groups, Gere comments upon the remarkable information Elbow also provides to extracurricular readers on how to create a teacherless writing group: "Elbow includes suggestions on qualities to seek in group members, procedures for running the 'class,' and difficulties to avoid... In other 
words, Elbow provides a 'kit' for persons wishing to establish their own writing groups" (Gere 1987, p. 49). The different strategies Elbow detailed for building a teacherless writing class grew from self-help notions of the unconscious and holistic dimensions of writing.

Elbow's strategies were adopted in the 1970s and 1980s by writing scholars into an array of teaching practices ubiquitous to current college and university writing programs: breaking students into feedback groups, developing rough and early drafts, freewriting, and writing to self-express. These days, you would be hard-pressed to find a writing instructor who has not in some way been exposed to the self-help ideas of Elbow's early book. Indeed, Elbow's extracurricular ideas about writing became foundational to process pedagogy — a whole branch of teaching and theory which in turn helped establish Composition Studies as an academic discipline in the university (Crowley 1998; see also Connors 2003). Elbow's book and the process movement are frequently described as causing a whole paradigm shift in writing education and as energizing scholars to teach in whole new student-centered ways that fostered more lively and expressive writing in students (Hairston 1982; See also Freisinger 1994). Writing Without Teachers has functioned as writing scholars' self-help reading, much like a person with relationship woes might pick up Men are From Mars, Women from Venus. In the mid-1970s, writing faculty were dissatisfied with conventional classroom procedure which involved little student writing, much lecture, and a great deal of lifeless writing in response to rote tasks (Enos 2010). Needing help, wanting to fix their own teaching practices, instructors readily picked up and read Writing Without Teachers as a self-help book.

\section{CONCLUSION}

By providing an alternative to classroom writing education, self-help books have given countless individuals the opportunity for a Deweyan encounter with their own creative texts. As such, self-help books, far from commercial fluff, are powerful egalitarian forces, allowing all sorts of people - not only students, teachers, or professional authors-to learn about the art of writing on their own time, separate from a teacher, an assignment, or a grade. In positing that everyone has the ability to write, self-help books provide an affirmative learning environment to counteract negative messages about writing sometimes arising from years of classroom instruction. More importantly, the general public's interest in the 
content of self-help books on writing suggests a need for such content in the textbooks and instruction of formal aesthetic education. Taken seriously, self-help literature on writing not only has much to offer the general public and prospective authors in terms of education: it has much to offer those of us who are invested in providing a highly effective-and indeed affective-classroom learning experience.

Acknowledgements From Journal of Aesthetic Education. Copyright 2014 by the Board of Trustees of the University of Illinois. Used with permission of the University of Illinois Press.

\section{REFERENCES}

Alexander, Thomas M. 1987. John Dewey's Theory of Art, Experience \& Nature: The Horizons of Feeling. New York: State University of New York Press.

Applebee, Arthur N. 1974. Tradition and Reform in the Teaching of English: A History. Urbana, IL: NCTE Press.

Berlin, James A. [1985] 1987. Rhetoric and Reality: Writing Instruction in American Colleges, 1900-1985. Carbondale, IL: Southern Illinois University Press.

Brande, Dorothea. [1934] 1981. Becoming a Writer. New York: Tarcher and Harcourt, Brace, \& Co.

Connors, Robert J. 2003. Composition History and Disciplinarity. In Selected Essays of Robert J. Connors, ed. Lisa Ede and Andrea A. Lunsford, 405-422. Boston: Bedford/St. Martins.

Crowley, Sharon. 1998. Composition in the University: Historical and Polemical Essays. Pittsburgh: University of Pittsburgh Press.

DeFrancisco, Victoria Leto. 1995. Helping Ourselves: An Introduction. Women's Studies in Communication 18 (2): 107-110.

Dewey, John. 1929. Affective Thought in Logic and Painting. In Art and Education, ed. John Dewey et al. Rahway, NJ: Barnes Foundation Press.

- 1934. Art as Experience. New York: Perigee Books.

Dolby, Sandra K. 2005. Self-Help Books: Why Americans Keep Reading Them. Chicago: University of Chicago Press.

Elbow, Peter. [1973] 1998. Writing Without Teachers. Oxford: Oxford UP.

- 1998. Writing with Power. Oxford: Oxford University Press.

- 2009. Interview with author. July 27.

Emig, Janet. 1964. The Uses of the Unconscious in Composing. College Composition and Communication 15 (1): 6-11.

Enos, Theresa. 2010. Telephone interview. 15 July. 
Gere, Anne Ruggles. 1987. Writing Groups: History, Theory, and Implications. Carbondale, IL: Southern Illinois University Press.

- 1994. Kitchen Tables and Rented Rooms: The Extracurriculum of Composition. College Composition and Communication 45 (1): 75-92.

Goldberg, Natalie. [1986] 2005. Writing Down the Bones: Freeing the Writer Within. Boston: Shambhala.

Graff, Gerald. 1987. Professing Literature: An Institutional History. Chicago: University of Chicago Press.

Haake, Katharine. 2000. What Our Speech Disrupts: Feminism and Creative Writing Studies. Urbana, IL: NCTE Press.

Hairston, Maxine. 1982. The Winds of Change: Thomas Kuhn and the Revolution in the Teaching of Writing. College Composition and Communication 33 (1): 76-88.

Freisinger, Randall R. 1994. Voicing the Self: Toward a Pedagogy of Resistance in a Postmodern Age. In Landmark Essays on Voice and Writing, ed. Peter Elbow, 187-211. Davis, CA: Hermagoras Press.

Hashimoto, I. 1994. Voice as Juice: Some Reservations About Evangelic Composition. In Landmark Essays on Voice and Writing, ed. Peter Elbow. 187-211. Davis, CA: Hermagoras Press.

Hughes, Elaine Farris. 1994. Writing from the Inner Self. New York: HarperCollins.

Kaminer, Wendy. 1992. I'm Dysfunctional, You're Dysfunctional: The Recovery Movement and Other Self-Help Fashions. Reading, MA: Addison-Wesley Publishing Company.

Kirsch, Gesa E. 2009. From Introspection to Action: Connecting Spirituality and Civic Engagement. College Composition and Communication 60 (4, June): Wl-W15.

Lamott, Anne. 1995. Bird by Bird: Some Instructions on Writing and Life. New York: Anchor and Random House.

Lee, Helen. 2007. 'Truths That Set Us Free?' The Use of Rhetoric in MindBody-Spirit Books. Journal of Contemporary Religion 22 (1): 91-104.

Macrorie, Ken. 1991. The Freewriting Relationship. In Nothing Begins with N: New Investigations of Freewriting, ed. Pat Belanoff, Peter Elbow and Sheryl I. Fontaine, 173-175. Carbondale, IL: Southern Illinois University Press.

McGee, Micki. [1989] 2005. Self-Help, Inc.: Makeover Culture in American Life. Oxford: Oxford University Press.

Mearns, Hughes. 1925. Creative Youth. New York: Doubleday.

- 1929. Creative Power. New York: Doubleday.

- 1940. The Creative Adult: Self-Education in the Art of Living. New York: Doubleday.

Miller, Susan. 1991. Textual Carnivals: The Politics of Composition. Carbondale, IL: Southern Illinois University Press. 
Moroye, Christy M., and P. Bruce Uhrmacher. 2009. Aesthetic Themes of Education. Curriculum \& Teaching Design 11 (1-2, September): 85-101.

Murray, Donald. 1970. The Interior View. College Composition and Communication 21 (1): 21-26.

Myers, D.G. 1996. The Elephants Teach: Creative Writing Since 1880. Englewood Cliffs, NJ: Prentice Hall.

Newkirk, Thomas. 2002. Sentimental Journeys: Anti-Romanticism and Academic Identity. In Writing with Elbow, ed. Pat Belanoff et al., 21-33. Logan, UT: Utah State University Press.

- 2005. The School Essay Manifesto: Reclaiming the Essay for Students and Teachers. Shoreham, Vermont: Discover Writing Press.

Papoulis, Irene. 2002. Pleasure, Politics, Fear, and the Field of Composition: Elbow's Influence on My Theorizing and Teaching. In Writing with Elbow, ed. Pat Belanoff, 159-171. Logan, Utah: Utah State University Press.

Perl, Sondra. 2004. Felt Sense: Writing with the Body. Portsmouth, NH: Boynton/Cook Heinemann.

Richmond, Kia Jane. 2002. Repositioning Emotions in Composition Studies. Composition Studies 30 (1): 67-82.

Ritter, Kelly. 2007. Ethos Interrupted: Diffusing 'Star' Pedagogy in Creative Writing Programs. College English 69 (3): 283-292.

Rudolph, Frederick. 1962. The American College and University: A History. New York: Knopf.

Seel, Martin. 2009. On the Scope of Aesthetic Experience. In Aesthetic Experience, ed. Richard Shusterman and Adele Tomlin. New York: Routledge.

Shusterman, Richard. 2001. Pragmatism. In The Routledge Companion to Aesthetics, ed. Berys Gaut and Dominic McIver Lopes. New York: Routledge.

- 2004. On the Origin of Self-Help. Economist 371 (8372, 24 April): 86.

- 2008. Body Consciousness: A Philosophy of Mindfulness and Somaesthetics. Cambridge: Cambridge University Press.

Starker, Steven. 1989. Oracle at the Supermarket: The American Preoccupation with Self-Help Books. New Brunswick: Transaction Publishers.

Stine, Jean Marie. 1997. Writing Successful Self-Help \& How-To Books: An Insider's Guide to Everything You Need to Know. New York: Wiley.

Tiede, Tom. 2001. Self-Help Nation: The Long Overdue, Entirely Justified, Delightfully Hostile Guide to the Snake-Oil Peddlers Who Are Sapping Our Nation's Soul. New York: Atlantic Monthly Press.

Tobin, Lad. 1989. Bridging Gaps: Analyzing Our Students' Metaphors for Composing. College Composition and Communication 40 (4): 444-458.

Ueland, Brenda. 1938. If You Want to Write: A Book About Art, Independence, and Spirit. Minneapolis: Graywolf Press. 
Whitehead, Derek. 2004. The Pedagogical Aesthetic and Formative Experience: Educating for Aletheic Imagination in the Fine Arts Curriculum. Journal of Visual Art Practice 3 (3, October): 195-208.

Woodstock, Louise. 2006. All About Me, I Mean, You: The Trouble with Narrative Authority in Self-Help Literature. The Communication Review 9: 321-346.

Open Access This chapter is licensed under the terms of the Creative Commons Attribution 4.0 International License (http://creativecommons.org/licenses/ by $/ 4.0 /)$, which permits use, sharing, adaptation, distribution and reproduction in any medium or format, as long as you give appropriate credit to the original author(s) and the source, provide a link to the Creative Commons license and indicate if changes were made.

The images or other third party material in this chapter are included in the chapter's Creative Commons license, unless indicated otherwise in a credit line to the material. If material is not included in the chapter's Creative Commons license and your intended use is not permitted by statutory regulation or exceeds the permitted use, you will need to obtain permission directly from the copyright holder.

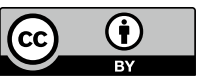

